\title{
Directions in National Water Research Policy and Funding
}

\author{
Erik K. Webb
}

Office of U.S. Senator Pete Domenici

$\mathrm{W}$ ater policy and water research have been relatively low profile over the last several years as larger issues have grabbed the headlines. Occasionally, as drought becomes particularly pervasive a bit of news trickles out in the national media (Johnson and Murphy 2004). Nevertheless, far-reaching legislative and executive activities are underway. The question remains, what impact will these Federal actions have in resolving our long-term water supply needs?

\section{The State of Our Water Resources}

Our water resources are stressed nationwide (Gleick 2005). State water managers have identified current and future water stressed areas (General Accouting Office 2003). The stress can be measured by lack of water or by actual areas of conflict or potential conflict (Bureau of Reclamation 2005a). These conflicts can occur between any of the specific water interests such as agriculture and environment (Snyder 2003) or energy and water supply (Department of Energy 2006). To exacerbate these issues, a major drought raged in the Western U.S. from 1999 to 2006 and remains unabated in the desert southwest (National Oceanic and Atmospheric Administration 2006). In some regions of the country, population is anticipated to grow by astonishing amounts over the next twenty years. Of particular importance is that the regions with the most severe current droughts are likely to grow the most (Bureau of Reclamation 2005a). At the same time, we don't have a solid understanding of our national water resources, either surface or ground water
(Subcommittee on Water Availability and Quality 2004); this remains an obstacle to optimal management of the existing supplies.

\section{What Options Exist for Balancing Supplies and Demands?}

A broad array of solutions have been proposed and implemented to match water supplies and water demands. The initial approaches all focused on expanding or better accessing usable water supplies. Water transfers between various locations have occurred across the west (National Research Council 1992) and new projects are under consideration (U.S. News 2003). Available water has been increased through expanded storage capacity in reservoirs (Bureau of Reclamation 2005b) or through subsurface storage (National Research Council 2002). Additional reservoirs are under construction (Bureau of Reclamation 2006a) or are proposed (Pueblo Chieftain 2006) and expansion of existing reservoirs is under consideration (Bureau of Reclamation 2006b). Water augmentation through cloud seeding remains an active area of consideration (American Society of Civil Engineers 2006), but its efficacy is in question (National Research Council 2004a). Pumping groundwater has been a mainstay (Hutson et al. 2005) and in periods of drought the reliance on groundwater increases. However, it is clear that many of the aquifers in our nation are unsustainable (McGuire et al. 2000).

When the primary sources of water become fully utilized or stressed in some way, communities turn to temporary restrictions (Santa Fe 2006), long-term efficiency improvements (Environmental Protection 
Agency 2002), transfers between uses (Hanak 2003), and finally various forms of water treatment (Bureau of Reclamation 2003).

Generally, restrictions and efficiencies are locally controlled decisions (Environmental Protection Agency 2002). Theoretically, continued improvement in efficiency can greatly impact the balance of supply and demand if one assumes absolute minimum acceptable amounts of fresh water (United Nations 2003) ${ }^{1}$; however, there are likely to be practical limits to efficiency improvement.

Transfers between uses are decisions jointly managed by local and either county or state governments that, in the U.S., are primarily the result of economic factors moving water from low economic value to some higher economic value (Hanak 2003). In the western U.S., transfers occur primarily between agriculture and municipal or industrial uses (Raley 2002). Water transfers require some form of legal structure or water market such as water banking. These economic and legal systems are not fully developed over most of the U.S. today (Hanak 2003) but are expanding (Anderson and Leal 1988). It is not clear how much water will be transferred this way, but there are likely limits. We are already beginning to see state-based legislation to slow or prevent these transfers and their impacts on third parties in California (Hanak 2003) and Oregon (U.S. Department of Agriculture 2004).

Water treatment has been advocated for decades. President Kennedy was a strong proponent ${ }^{2}$ (Kennedy 1961), but our nation's investment in water augmentation technology development has diminished precipitously since the late 1960s (National Research Council 2004b) and is pursued in a limited number of institutions (Council on Environmental Quality 2005).

The recognition of the importance of advanced water treatment is very high (Subcommittee on Water Availability and Quality 2004). There are many communities who recognize the immediate need for large water treatment needs such as El Paso (El Paso 2005) and many communities in California (U.S. Desalination Coalition 2006). Florida has long used desalination (University of Hawaii 1999) and will step up its use (Tampa 2006); cities along the Gulf of Mexico in Texas (Texas Water Development Board 2006), and some eastern cities such as Boston (ContractorMag, 2005) also use desalination.

\section{Federal Policy Development}

In any one year, the President issues a recommendation of national priorities in the form of the administration's budget request (Office of Management and Budget 2006). Congress in turn sends a modified version back to the Whitehouse (Public Law 109-103). Both are motivated by broad policy considerations and local politics. Unfortunately, both of these budget exercises are subdivided into multiple budget elements based on the twenty or so agencies that each have a hand in water resources management in the U.S. The likelihood that the many budget elements overlap or conflict is high.

Within the Executive Branch, water resources figure prominently in the annual science priorities outlined jointly by the President's chief science advisor (head of the Whitehouse Office of Science and Technology Policy) and the head of the Office of Management and Budget (Marburger and Bolten 2005).

Under the direction of the Office of Science and Technology Policy, the Subcommittee on Water Availability and Quality (SWAQ) has been working with twenty Federal agencies to assess and prioritize science and technology-related activities that can be undertaken to provide water and protect water quality. Their first report, completed November 2004 and released in February 2005 (Subcommittee on Water Availability and Quality 2004) identified the following needs:

- A comprehensive assessment of water availability and use, including examination of trends related to both, is overdue.

- Without quantifiable and scientifically defensible estimates of environmental water requirements, water gridlock-intense competition among irrigation, navigation, municipal supply, energy, and the environment - is unlikely to be resolved.

- Some waters are not considered to be a resource, yet should be. Further research and development about water reuse, desalination, aquifer storage and recovery may provide ways to meet the challenge of providing high-quality water to our citizens.

- The socioeconomic factors that determine water use are not fully understood. Yet, those factors will be a key to getting the most benefit from available and emerging water-saving technologies.

- Planning and efficient operation of water infrastructure depend on water forecasts that are 
valid over times of hours to months. Water managers need improved river forecasts, including recognition of the role of ground water in those forecasts.

A second report from the SWAQ with recommendations on how to address these obvious needs is anticipated to be released in 2006.

The Council on Environmental Quality within the Whitehouse assessed water reuse programs in the Federal agencies and concluded that, "the range of federal programs that explicitly address 'water reuse, recycling, and reclamation' in their statutory authorization is quite limited. In the various federal statutes pertaining to water resources, there is little direct authorization or regular funding for federal water reuse programs," although there are programs for both development and implementation of planned water reuse in the Bureau of Reclamation (DOI), EPA, Department of Defense, USAID and USDA (Council on Environmental Quality 2005).

The National Academies completed a study of water resources research funding in 2004. They concluded that the number of water problems and their severity were both increasing, but that investment in water resources research had remained flat for over thirty years. Additionally, investment in research to expand water supplies both legally, institutionally, and technically had been cut dramatically. As a consequence, they recommended that "the nation must invest not only in applied research but also in fundamental research that will form the basis for applied research a decade hence. A repeat of past efforts will likely lead to enormously adverse and costly outcomes for the status and condition of water resources in almost every region of the United States" (National Research Council $2004 b)$. One section of that report identified the expenditures for "water augmentation" research. The research funding in this area, based on 2000 dollars, had decreased from about $\$ 140$ million a year in the late 1960 s and early 1970 s to around $\$ 10$ million around 2000. This is the category of research and development that was the source of today's membrane technology.

The American Water Resources Association (AWRA) held its second discussion of national water policy in February 2005 with participants from across the nation. One recommendation from the workshop was to create yet another water policy commission to address issues including,
... defining national goals and a vision for sustainable water resources management and determining, in cooperation with state, tribal, and local governments, how best to address competing economic, social, and environmental objectives. Clearly defining the respective roles of federal, state, tribal and local governments and other stakeholders in dealing with water issues - quality and quantity, floods and droughts, hydropower, navigation and the water needs of the natural environment. Conducting an assessment of the status of the Nation's water resources to determine critical needs and vulnerabilities and our ability to acquire and maintain the scientific data upon which such assessments must be based. Examining federal laws, regulations, Executive Orders and governmental guidance in the water arena to identify conflicts and inconsistencies and to recommend legislative actions needed to better harmonize water policies and address water resources issues (American Water Resources Association 2005).

The Senate Energy and Natural Resources Committee held a workshop on water resources in Washington DC on April 5, 2005 to address (1) Water Supply and Resources Management Coordination, (2) The future of the U.S. Bureau of Reclamation, (3) Indian and Reserve Federal Water Rights, and (4) Conservation and Technology Development / Knowledge of Water Resources. Approximately thirty-five participants presented their views on these issues, including many participants from the executive branch. At the workshop, several recommendations were presented including: (1) the need for the Federal government to increase investment in water availability technology, (2) "the need to reconcile the myriad laws, executive orders, and congressional guidance that have created disjointed ad-hoc national water policy," (3) that investment in action may be better than investing in another policy commission, (4) the need for much better interagency coordination in managing water resources, and (5) the need for research on current surface and ground water availability (Eichenseher 2005).

The Center for Strategic and International Studies (CSIS) has led an effort to assess current U.S. policy relative to international water resources. In 2004 and 2005, CSIS worked with Sandia National Laboratories to hold a series of workshops to address this issue resulting in a report that identified that, 
Institutional capacities in governance systems across the world (varied as they are) must all be strengthened in various ways to adequately address the magnitude of future challenges involving water. Improving governance will enable and facilitate the development of strategies and responses engaging the full range of available water-related technologies - from high-tech, high expense to low-tech, low expense. Solutions across that range exist today and must be deployed at new and greater scales in order to reduce the impacts on public health, economic development, and political stability. Continual effort and investment is needed to develop yet unknown technologies, policy approaches, and synergies that could jumpstart new solutions for addressing this growing global crisis in the decades to come. Policy and technology must evolve together to effectively link innovative strategies with innovative technologies. Innovation and synergy are the keys (Center for Strategic and International Studies 2005).

The report helped to formulate and pass the Safe Water: Currency for Peace Act of 2005 which made it official U.S. policy, "(1) to promote good health and economic development by providing assistance to expand access to safe water and sanitation, promote sound water management, and improve hygiene for people around the world; and (2) to promote, to the maximum extent practicable and appropriate, longterm sustainability in the provision of access to safe water and sanitation by encouraging private investment in water and sanitation infrastructure and services" and also created a pilot program for creation of clean water and sanitation infrastructure in countries with high water-borne illness issues (Public Law 109-121).

There is a legitimate question about how much and what type of information and analysis is needed to adequately understand our water resources. The Federal Government has reconstituted the Advisory Committee on Water Information (ACWI). "The purpose of this Presidential Committee is to represent the interests of water-information users and professionals in advising the Federal Government on Federal waterinformation programs and their effectiveness in meeting the Nation's water-information needs. Member organizations help to foster communications between the Federal and non-Federal sectors on sharing water information. Membership represents a wide range of water resources interests and functions. Representation on the ACWI includes all levels of government, academia, private industry, and professional and technical societies" (U.S. Geological Survey 2006). The work group periodically meets to coordinate water data sharing and develop standard formats, share information on optimal methods for data collection and in general coordinate federal and non-federal data sharing.

\section{Selective Innovative Solutions}

A new initiative to support water planning numerical tools resulted in a Computer Aided Dispute Resolution (CADRE) program within the Army Corps of Engineers' Institute of Water Resources in partnership with Sandia National Laboratories and the Bureau of Reclamation. This effort combines computer simulation that is understood and manipulated by non-technical decision-makers with long-term planning to make sure that proposed plans are technically feasible and that all participants have the same understanding of the long-term outcomes. These tools have been applied to rivers in New Mexico, Oregon, Maryland, and Minnesota as well as the regions within the Great Lakes. Training of multiple users and expansion of this program are underway in 2006 and 2007.

In the area of expanding water supplies through water treatment, there are two key issues. First, does the Federal government have the responsibility to provide funding for water treatment systems and if so under what circumstances? Second, how can the Federal government help augment and integrate research into improving economic, energy, and social hurdles associated with increased bulk water treatment through technology development, modification of regulations, and other actions? Both of these questions remain active areas of debate. Nevertheless, there are an array of specific activities within the Federal agencies directed to expand technology for water treatment.

A critical effort was the Desalination Roadmap (Bureau of Reclamation 2003) developed in 2003 and reviewed by the National Academies in 2004 (National Research Council 2004c). The Roadmap outlined the research agenda for both incremental and large increases in efficiency for desalination technology. Initial funding for work related to this roadmap has been allocated through a consortium of Federal groups including the U.S. Bureau of Reclamation (BOR) and the Department of Energy through Sandia National Laboratories and non-Federal entities such as the California Department of Water 
Resources, WateReuse Foundation, and the American Water Works Association Research Foundation.

The Bureau of Reclamation's desalination research program is the grandfather of federal agency efforts to develop water treatment and desalination. Researchers in this program were the source of much of our understanding of membrane technology; it is a broad research program that includes water reuse and supports three research facilities. The first is the Yuma Desalination plant on the lower Rio Grande River, the second is the recently completed Long Beach Desalination Facility, and the third is the Tularosa Desalination Plant under construction in New Mexico. The research program operates under multiple authorities. The first is a broad research mandate that BOR has interpreted to allow inhouse expenditure of funds. The second was the National Desalination Research Act, originally championed by the late Senator Paul Simon passed in 1996 (Public Law 104-298) and reauthorized by Senator Domenici each year since 2001. It is this second authority that allows the BOR to send funds to universities and other external programs. Over the last several years funding for this program has been zeroed out in the President's budget request to Congress but maintained by Congress. The third is a grant authority carried annually by Congress that underpins the Bureaus Water 2025 program. This authority allows the Bureau to provide community and state grants related to reuse and desalination.

The Office of Naval Research (ONR) also has an active research program directed at producing working integrated water treatment systems for either mobile (expeditionary units) or to replace aging systems aboard ships. The first of these integrated systems, capable of treating 100,000 gallons a day, operated by a crew of four to six, and sized for transport in a C-130 aircraft was deployed for testing in February 2005. Additionally, in 2004 the ONR began to issue research grants to support the next version of this equipment targeted for 500,000 gallons a day.

The Department of Energy began a research program in desalination with funding from 2003; however, the funds were not made available until the end of fiscal year 2004 so the program is relatively new. These funds are directed at next generation research and are aligned with a research roadmap jointly developed by the Bureau of Reclamation and Sandia National Laboratories. This program has been funded at approximately \$3-4 million a year.
Combined, these programs represent a Federal investment of $\$ 24$ million for 2006 or about 20 percent of the investment we had in water augmentation in 1970 (National Research Council 2004b).

\section{Conclusion}

The interest in water resources management is growing exponentially as communities in both the semi-arid west and the humid east face water supply shortages. This ubiquitous interest has lead to an array of both Federal and non-Federal efforts to integrate water resources management, expand supplies, and address the relative responsibilities in water resources management of Federal and nonFederal parties. Nevertheless, integrated Federal Policy on water resources remains elusive.

\section{Acknowledgements}

The synopsis and comments contained in this paper are the sole responsibility of the author and are not intended to represent the views of any other individual or organization.

\section{Author Bio and Contact Information}

Erik WebB is a Detailee from the Department of Energy to the Staff of Senator Pete Domenici (NM) and served as a Congressional Fellow sponsored by the American Geophysical Union on the Senate Energy and Natural Resources Committee from 2003-2005. Prior to the Senate, he served as the manager of the Geohydrology Department at Sandia National Laboratories (SNL) in Albuquerque, NM. He has a BS in Engineering Geology from Brigham Young University, and an MS and $\mathrm{PhD}$ from the University of Wisconsin in hydrogeological modeling. He is a member of the Japanese Nuclear Waste Management Organization's International Technical Advisory Committee and is adjunct faculty at the University of New Mexico. Erik_Webb@dominici.senate.gov

\section{Notes}

1. The United Nations World Water Development Report cites $1000 \mathrm{~m}^{3} /$ year as minimum for basic nutrition $=725 \mathrm{gal} /$ day for all uses including home, industry, energy, agriculture.

2. "Today is an important step towards the achievement of one of man's oldest dreams, to secure fresh water from salt water. I can think of no cause and no work which is more important not only to the people of this country, but to people all around the globe, especially those who live in deserts or on the edge of oceans." 


\section{References}

Anderson, T. L. and D. R. Leal. 1988. Going with the Flow: Expanding the Water Markets by Cato Institute. Cato Policy Analysis No. 104, 1988, http://www.cato.org/pubs/pas/ pa104.html.

American Society of Civil Engineers. 2006. Guidelines for Cloud Seeding to Augment Precipitation, Second Edition. ASCE Manuals and Reports on Engineering Practice No. 81 American Society of Civil Engineers, 200 p.

American Water Resources Association. 2005. Letter from the American Water Resources Association to Senator Pete Domenici dated April 7, 2005 in reference to questions asked at the Senate Energy and Natural Resources Committee workshop on water resources April 5, 2005 Washington, DC.

Bureau of Reclamation. 2003. Desalination and Water Purification Technology Roadmap, a Report of the Executive Committee, Sandia National Laboratories and the U.S. Bureau of Reclamation, 83 p.

Bureau of Reclamation. 2005a. Water 2025, Preventing Conflict and Crisis in the West, Water 2025 Status Report August 2005, Bureau of Reclamation, $36 \mathrm{p}$.

Bureau of Reclamation. 2005b. Inventory of Reclamation Water Surface Storage Studies with Hydropower Components, Report to Congress Implementing Provisions of Section 1840 of the Energy Policy Act of 2005 (Public Law 10958) October 2005.

Bureau of Reclamation. 2006a. Animas La-Plata Project, Implementation of the Colorado Ute Settlement Act Amendments of 2000. http://www.usbr.gov/uc/progact/ animas/.

Bureau of Reclamation. 2006b. Los Vaqueros Expansion Investigation, California, CALFED Project http://www. usbr.gov/mp/vaqueros/index.html.

Center for Strategic and International Studies. 2005. Addressing our Global Water Future, Center for Strategic and International Studies and Sandia National Laboratories, May 8, 2005.

Council on Environmental Quality. 2005. Council on Environmental Quality report to Congress October 3, 2005 on Federal Agency Water Reuse Program.

ContractorMag. 2005. Mass Towns Mull Desalination, ContractorMag.com. http://www.contractormag.com/ articles/newsarticle.cfm?newsid $=454$.

Department of Energy. 2006. Diminishing Water Resources and Expanding Energy Demands: The Energy Water Nexus in the United States, Draft Report to Congress, November 18, 2005 (in review with OMB).

Eichenseher. T. 2005. Senate panelists back Domenici water supply legislation. E\&E Daily Wednesday April 6, 2005.

El Paso. 2005. Ten Year Strategic Plan. El Paso Water Utilities, Dec 2005, 32 p.

Environmental Protection Agency. 2002. Case in Water Conservation: How Efficiency Programs Help Water
Utilities Save Water and Avoid Costs. U.S. Environmental Protection Agency Report. 49 p.

General Accounting Office. 2003, Freshwater Supply: States' Views on How Federal Agencies Could Help Them Meet the Challenges of Expected Shortages, Government Accounting Office Report to Congressional Requestors, GAO-03-514 July 9, 2003, 110 p.

Gleick. P.H. (ed.) 2005. The World's Water 2004-2005: The Biennial Report on Freshwater Resources, Pacific Institute, Island Press.

Hanak, E. 2003. Who Should Be Allowed to Sell Water in California? Third Party Issues and the Water Market, Public Policy Institute of California, $171 \mathrm{p}$.

Hutson. S. S., N. L. Barber, J. F. Kenny, K. S. Linsey, D. S. Lumia, and M. A. Maupin. 2005. Estimated Use of Water in the United States in 2000. USGS Circular 1268.

Johnson, K. and D. Murphy. 2004. Drought Settles In, Lake Shrinks and West's Worries Grow, May 2, 2004, Sunday New York Times.

Kennedy, J. F. 1961. Dedication remarks by President Kennedy, Freeport, Texas, at the Dow Texas Division September 22, 1961. http://news.dow.com/dow_news/feature/2001/04 11_01/index.htm.

Marburger, J. H. and J. B. Bolten. 2005. July 8, 2005, Memorandum for Heads of Executive Departments and Agencies, FY2007 Administration Research and Development Budget Priorities, John H. Marburger III, Director, Office of Science and Technology Policy and Joshua B. Bolten, Director, Office of Management and Budget, section on Energy and Environment, p. 5.

McGuire, V. L., M. R. Johnson, R. L. Schieffer, J. S. Stanton, S. K. Sebree, and I. M. Verstraeten. 2000. Water in Storage and Approaches to Ground-Water Management, High Plains Aquifer. USGS Circular $124351 \mathrm{p}$.

National Oceanic and Atmospheric Administration. 2006. NOAA Climate Data Center - http://www.ncdc.noaa.gov/ oa/climate/research/monitoring.html.

National Research Council . 1992. Water Transfers in the West: Efficiency, Equity, and the Environment. National Academies Press, Commission on Geosciences, Environment and Resources, $300 \mathrm{p}$.

National Research Council. 2002. Regional Issues in Aquifer Storage and Recovery for Everglades Restoration: A Review of the ASR Regional Study Project Management Plan of the Comprehensive Everglades Restoration Plan. Water Science and Technology Board, National Research Council. National Academies Press. 63 p.

National Research Council. 2004a. Critical Issues in Weather Modification Research. National Research Council Report. National Academies Press.

National Research Council. 2004b. Confronting the Nation's Water Problems, the Role of Research. National Research Council Committee on Assessment of Water Resources, $214 \mathrm{p}$.

National Research Council. 2004c. Review of the Desalination and Water Purification Technology Roadmap. National Research Council, Water Science and Technology Board,. 76 p. 
Office of Management and Budget. 2006. Budget of the U.S. Government, Fiscal Year 2006, http://www.whitehouse. gov/omb/budget/fy2006/.

Public Law 104-298 Water Desalination Act of 1996.

Public Law 109-103 Energy and Water Development appropriations bill for FY2006.

Public Law 109-121 derived from Senate bill S.492.

Pueblo Chieftain. 2006. Aurora proposes storage in Box Creek, The Pueblo Chieftain April 21, 2006, http:/www.chieftain. com/metro/1145599200/8.

Raley, B.W. 2002. Testimony of Bennett W. Raley Assistant Secretary - Water and Science U.S. Department of the Interior Before the Committee on Resources, Subcommittee on Water and Power United States House of representatives on Implementation of the California Plan for the Colorado River: Opportunities and Challenges La Quinta, California, June 14, 2002.

Santa Fe. 2006. Santa Fe County Stage 3 Water Emergency Rules Mandatory Water Use Restrictions http://www.co.santa-fe.nm. us/departments/water_resources/water_restrictions.php.

Snyder, S. E., 2003. Negotiating High Stakes Water Conflicts: Lessons Learned from Experienced Practioners. University of Colorado Law School, October 31, 2003.

Subcommittee on Water Availability and Quality. 2004. Science and Technology to Support Fresh Water Availability in the United States. Report of the National Science and Technology Council, Committee on Environment and Natural Resources, Subcommittee on Water Availability and Quality, November 2004, 19 p.

Tampa. 2006. Tampa Bay Desalination Plant, Florida, Water-Technology.net, http://www.water-technology. net/projects/tampa/.

Texas Water Development Board. 2006. http://www.twdb.state. tx.us/Desalination/Desal/Index.asp.

United Nations. 2003. Water for People, Water for Life Executive Summary 2003. United Nations World Water Development Report.

University of Hawaii. 1999. Desalination in Florida and Worldwide, June 9, 1999, University of Hawaii, http:// www2.hawaii.edu/ nabil/desaltbk.htm.

U.S. Desalination Coalition. 2006. US Desalination Coalition Home Page - http://www.usdesal.org/.

U.S. News. 2003. Colorado Senate committee rejects Big Straw Study, March 2003, U.S. Water News Online, http://www. uswaternews.com/archives/arcsupply/3colsen3.html.U.S. Department of Agriculture. 2004. Agricultural Risks in a Water-Short World: Producer Adaptation and Policy Directions. A Workshop Summary for an Economic Research Service / Farm Foundation Workshop May 2425, 2004, Economic Research Service, U.S. Department of Agriculture, Washington, DC.

U.S. Geological Survey. 2006. Water Information Coordination Program, Advisory Committee on Water Information. http:// water.usgs.gov/wicp/acwi/. 